\title{
Late recognized nail aspiration in a child: case report
}

\author{
Çocukta geç farkedilen çivi aspirasyonu: Olgu sunumu
}

\author{
Ufuk ÇOBANOĞLU, ${ }^{1}$ Muhammed CAN, ${ }^{2}$ İsmail BİRİNCİĞLU,${ }^{3}$ Yeşim EDİRNE, ${ }^{4}$ Mehmet MELEK
}

Foreign body (FB) aspiration is common in children aged 0-3 years. Our case, a 2.5-year-old girl, presented with sudden onset of cough, fever and sputum; she had been treated twice for acute bronchitis four months ago. Resisting complaints led to an esophagoscopic examination in our Chest Surgery Clinic after a chest X-ray suggested FB in the esophagus, but no FB could be detected. A lateral chest X-ray revealed a FB with its sharp end targeting the trachea and its round end to the right hemithorax. Removal of the FB with forceps was not possible during rigid bronchoscopy. The FB was removed by thoracotomy and bronchotomy under general anesthesia. The removed FB was a nail measuring $6 \mathrm{~cm}$ in length. This case report should serve to stress the diversity of FB aspirations in childhood, the role of parental neglect, and that physicians should be aware of the possibility of FB in children with persistent cough.

Key Words: Aspiration; forensic case; foreign body.
Çocuklarda 0-3 yaş arası yabancı cisim (YC) aspirasyonu sık görülmektedir. Kız olgu, 4 ay önce ani başlayan öksürük, ateş ve balgam çıkarma şikayetiyle bir sağlık merkezinde akut bronşit tanısı ile iki kez tedavi edildi. Şikayetinin sürmesi üzerine, çekilen akciğer grafisinde özofagusta yabancı cisim şüphesi ile Göğüs Cerrahisi Kliniğimize sevk edilen olguya yapılan özofagoskopide YC görülmedi. Çekilen akciğer yan grafisinde, keskin ucu trakea orta hatta, yuvarlak ucu sağ hemitoraksa yönelmiş YC saptand1. Rijit bronkoskopi ile çıkarılamayan YC, torakotomi ve bronkotomi yöntemiyle genel anestezi altında çıkarıldı. YC $6 \mathrm{~cm}$ boyunda çivi idi. Bu sunum, çocukluk çağındaki YC aspirasyonlarının çeşitliliğini, hekimlerin sağlık kurumlarına inatçı öksürük şikayeti ile başvuran çocuklarda YC aspirasyonu olasılığına her zaman dikkat etmeleri gerektiğini ve ebeveyn ihmalini göstermek amacıyla hazırlanmıştır.

Anahtar Sözcükler: Aspirasyon; adli olgu; yabancı cisim.
Foreign body (FB) aspiration is a very common pediatric emergency, is especially seen in infants and children from lower socioeconomic groups and may be associated with high mortality and morbidity. ${ }^{[1-6]}$ Inhalation of a FB is usually accompanied by acute severe coughing, stridor, wheezing, and respiratory distress. This acute episode may escape the notice of parents, and the problem may manifest as an insidious chronic pulmonary problem, the cause of which may remain occult for a long period. ${ }^{[3,7]}$

In our study, we aimed to show an unusual case of FB aspiration from the Van area.

\section{CASE REPORT}

Our case was a 2.5-year-old girl, the seventh child of her parents; the family lived in a very small house. Her family was poor, with a monthly income of under US\$500. Four months ago, she has been admitted to a health center with recurrent cough, fever and sputum, and was diagnosed as acute bronchitis. In spite of medical treatment, her symptoms persisted and chest radiography was performed, which showed a FB measuring $6 \mathrm{~cm}$ in length. She was sent to a medical faculty in June 2008, where a chest X-ray performed in the chest clinic revealed a suspected nail, with the

\footnotetext{
Presented at the 1st International Eurasian Forensic Sciences Congress (October 8-11, 2008, Istanbul, Turkey).

Departments of ${ }^{1}$ Chest Surgery, ${ }^{2}$ Forensic Medicine, ${ }^{4}$ Pediatric Surgery,

Yuzuncu Yil University Faculty of Medicine, Van; Department of

Forensic Medicine, Karadeniz Technical University, Faculty of Medicine, Trabzon, Turkey.
}
1. Uluslararası Avrasya Adli Bilimler Kongresi’nde poster bildirisi olarak sunulmuştur (8-11 Ekim 2008, İstanbul).
Yüzüncü Yıl Üniversitesi Tıp Fakültesi, ${ }^{1}$ Göğüs Cerrahisi Anabilim Dalı,
${ }^{2}$ Adli Tıp Anabilim Dall, ${ }^{4}$ Cocuk Cerrahisi Anabilim Dall, Van;
${ }^{3}$ Karadeniz Teknik Üniversitesi Tıp Fakültesi, Adli Tıp Anabilim Dalı, Trabzon.


sharp end located in the mid-trachea and the round tip in the hemithorax (Fig. 1a, b). She was hospitalized. Laboratory results were normal except for an elevated white blood cell count of $11,000 / \mathrm{mm}$. Rigid esophagoscopy and bronchoscopy were planned. After endotracheal intubation, no FB was seen in the lumen of the esophagus by rigid esophagoscopy. The FB was identified in the trachea by fiberoptic bronchoscopy through the endotracheal tube. Rigid bronchoscopy was attempted, but after determining that the FB had
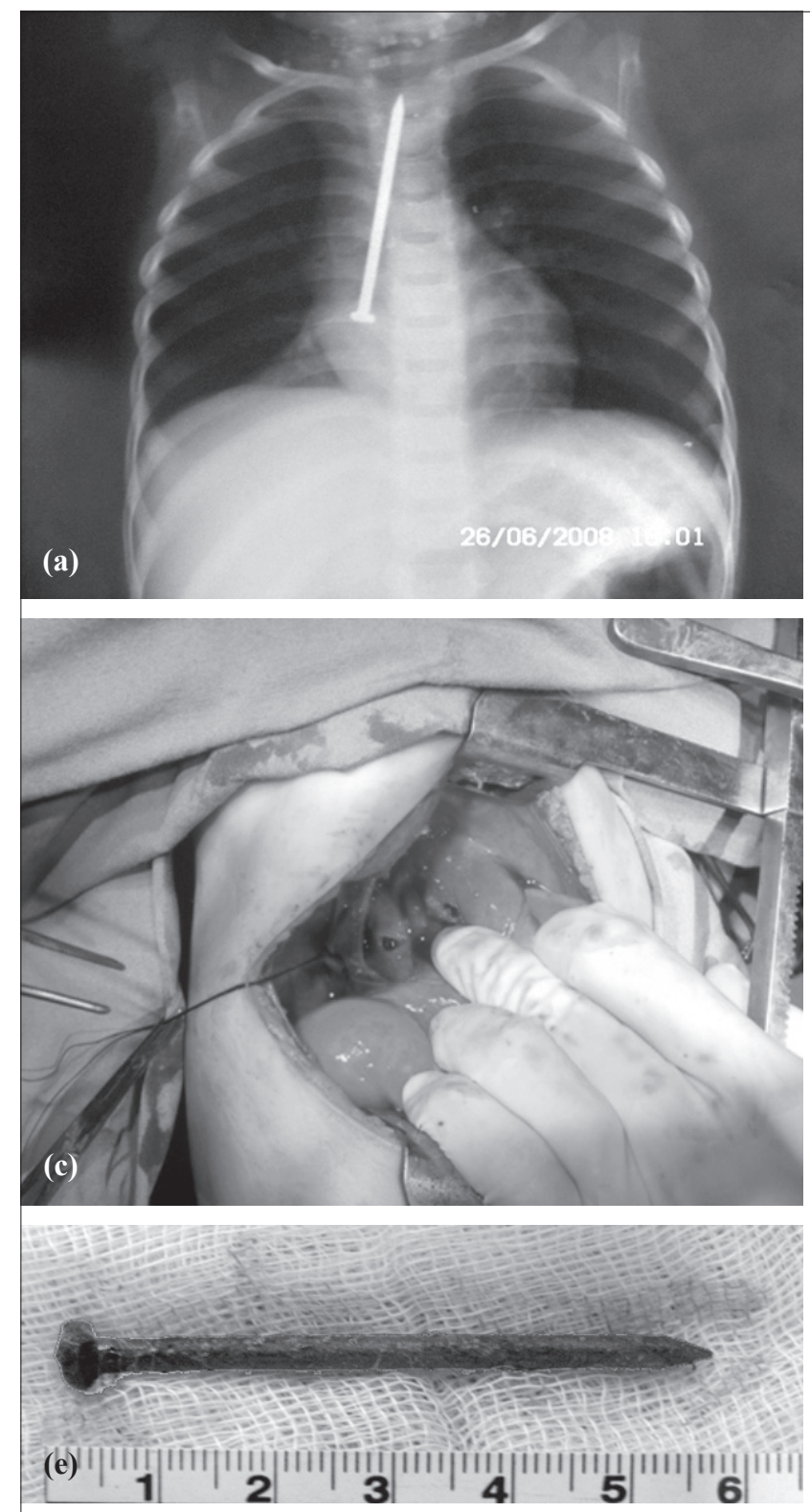

Fig. 1. (a) A direct chest X-ray revealed a foreign body with its sharp end targeting the trachea and its round end to the right hemithorax. (b) View of the foreign body in the lateral chest X-ray. (c) View of the foreign body in right main bronchus. (d) Extraction of the foreign body from the bronchotomy site. (e) Rusty nail extracted from the right main bronchus. (f) Postoperative chest X-ray of the patient. travelled from the right main bronchus to the carina, an open surgical procedure was planned. Under general anesthesia, after entering the thorax through the 5 th intercostal space, the azygos vein was tied and cut to ease approaching the main right bronchus. After appropriate and careful dissection, the right main bronchus was exposed. After sensation of the FB in right main bronchus by palpation, bronchotomy was done with a $0.5 \mathrm{~cm}$ incision (Fig. 1c). The FB in the bronchus was pushed to the trachea by means of a clamp.
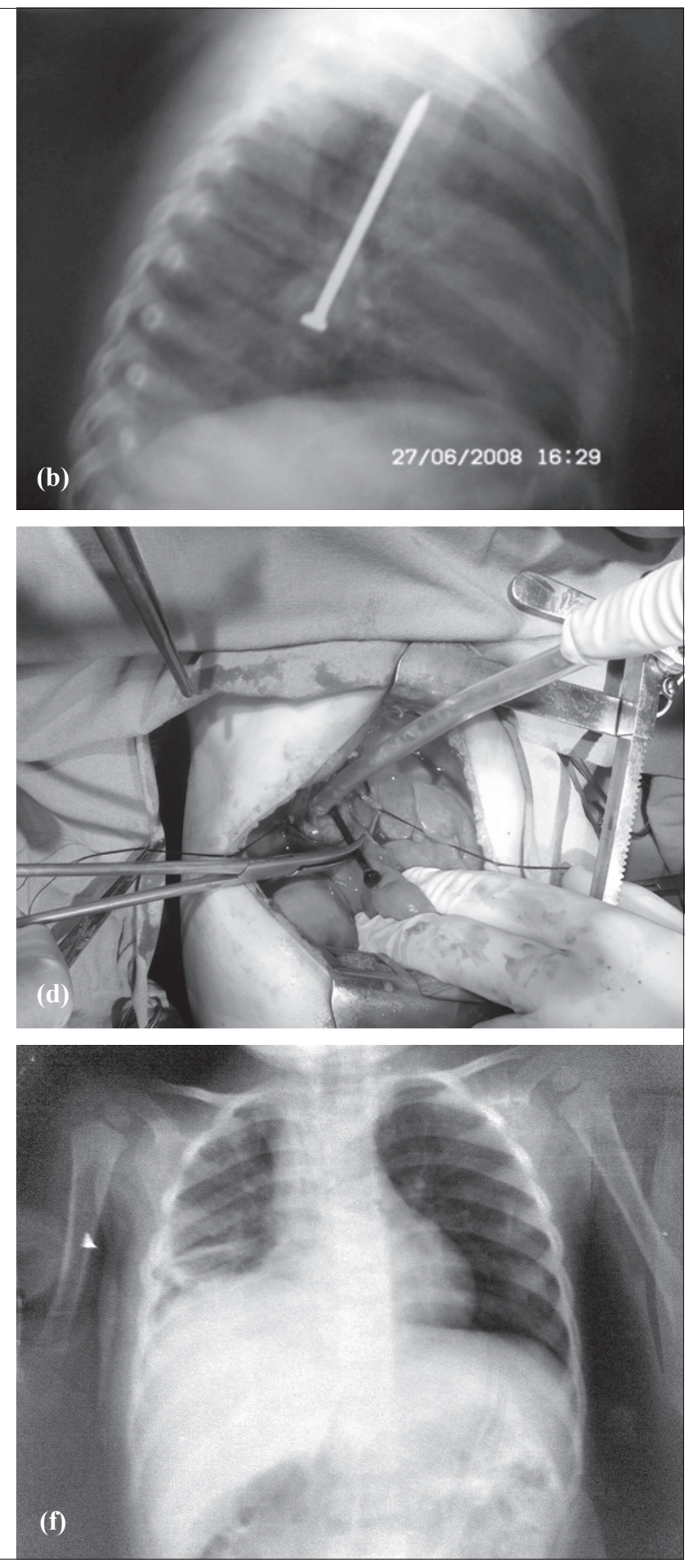
After visualization of the nail tip from the bronchotomy site, the FB was extracted by a clamp (Fig. 1d). The extracted FB was a nail as commonly used in construction. The nail was $6 \mathrm{~cm}$ in length and $1.2 \mathrm{~cm}$ in diameter and the top of the nail measured $0.6 \mathrm{~cm}$ (Fig. 1e). X-ray imaging of the chest on days $1,3,5$, and 9 and follow-up bronchoscopy on day 7 revealed no complication (Fig. 1f). Tetanus vaccination was not necessary according to her immunization history. The patient was discharged on day 9 and has been followed without any problem up to the 4th month.

\section{DISCUSSION}

More than $75 \%$ of FB aspiration cases are seen in children between $0-3$ years old. Additionally, $7 \%$ of deaths in children aged 0-3 years occur because of FB aspiration. ${ }^{[8,9]}$ Males are exposed more to FB aspiration, but with no known explanation. The ratio is approximately $2: 1 .^{[9-11]}$

FB aspiration is closely related to age, sex, culture, socioeconomic condition, and tradition. FB aspiration is seen frequently due to inadequate education and negligence, especially in developing countries. Poor safety precautions in construction areas may be dangerous for the neighboring community and especially children. ${ }^{[12]}$ Parents should carefully monitor small children playing around construction areas.

FB in the airway of children requires prompt removal. Ideal diagnostic methods would minimize unnecessary bronchoscopy for conditions that mimic airway FBs and avoid delay when patients with FBs require bronchoscopy. Textbook and journal articles have emphasized the importance of radiographic indicators of airway FBs. ${ }^{[13-16]}$

Early recognition and treatment of FB are very important because of possible early and late serious complications. Rigid bronchoscopy is the preferred method for removal of FB in children. ${ }^{[15]}$

In postponed cases, inflammation and granulation develop around the FB. Edema and/or purulent secretion are the basic mucosal changes observed in children. In cases treated in less than 24 hours, reaction is only expected in $0.8 \%$ of cases. Between 2-20 days or after 30 days, a tissue reaction is observed in $20 \%$ and $100 \%$, respectively. In these cases, thoracotomy and bronchotomy are applied. ${ }^{[16,17]}$ In our case, the FB was located in the right main bronchus for 4 months and a diffuse tissue reaction was detected. Therefore, bronchotomy was applied after rigid bronchoscopy failed to remove the FB.

In our study, we aimed to present an unusual case of FB aspiration from the Van area. This case report should remind physicians of the forensic perspective with respect to parental neglect, and physicians should be aware of the possibility of FBs in children with persistent cough.

\section{REFERENCES}

1. Anyanwu $\mathrm{CH}$. Foreign body airway obstruction in Nigerian children. J Trop Pediatr 1985;31:170-3.

2. O’Neill JA Jr, Holcomb GW Jr, Neblett WW. Management of tracheobronchial and esophageal foreign bodies in childhood. J Pediatr Surg 1983;18:475-9.

3. Kosloske AM. Bronchoscopic extraction of aspirated foreign bodies in children. Am J Dis Child 1982;136:924-7.

4. Altmann AE, Ozanne-Smith J. Non-fatal asphyxiation and foreign body ingestion in children 0-14 years. Inj Prev 1997;3:176-82.

5. Thompson GP, Utz JP, McDougall JC. Pediatric tracheobronchial foreign bodies. A case report. Minn Med 1993;76:1921.

6. Byard RW. Mechanisms of unexpected death in infants and young children following foreign body ingestion. J Forensic Sci 1996;41:438-41.

7. Aytaç A, Yurdakul Y, Ikizler C, Olga R, Saylam A. Inhalation of foreign bodies in children. Report of 500 cases. J Thorac Cardiovasc Surg 1977;74:145-51.

8. Steen KH, Zimmermann T. Tracheobronchial aspiration of foreign bodies in children: a study of 94 cases. Laryngoscope 1990;100:525-30.

9. Mantor PC, Tuggle DW, Tunell WP. An appropriate negative bronchoscopy rate in suspected foreign body aspiration. Am J Surg 1989;158:622-4.

10. Carluccio F, Romeo R. Inhalation of foreign bodies: epidemiological data and clinical considerations in the light of a statistical review of 92 cases. Acta Otorhinolaryngol Ital 1997; 17:45-51. [Abstract]

11. Ludemann JP, Holinger LD. Management of foreign bodies of the airway. In: Shields TW, LoCicero J, Ponn RB, editors. General thoracic surgery. 5th ed. Philadelphia: W.B. Saunders; 2000. p. 853-62.

12. Elhassani NB. Tracheobronchial foreign bodies in the Middle East. A Baghdad study. J Thorac Cardiovasc Surg 1988;96:621-5.

13. Orenstein DM. Foreign bodies in the larynx, trachea, and bronchi. In: Behrman RE, Kleigman RM, editors. Nelson textbook of pediatrics. 15th ed. Philadelphia, PA: Saunders; 1996. p. 1205-8.

14. Boyd AD. Endoscopy: Bronchoscopy and esophagoscopy. In: Sabiston DC, Spencer FC, editors. Surgery of the chest. 6th ed. Philadelphia, PA: Saunders; 1995. p. 81-4.

15. Yıldırım M, Doğusoy I, Okay T, Yasaroğlu M, Demirbağ $\mathrm{H}$, Aydemir B, et al. Trakeobronsiyal yabancı cisimler. Türk Göğüs Kalp Damar Cer Derg Surg 2003;11:228-31.

16. Karakoç F, Karadağ B, Akbenlioğlu C, Ersu R, Yildizeli B, Yüksel $\mathrm{M}$, et al. Foreign body aspiration: what is the outcome? Pediatr Pulmonol 2002;34:30-6.

17. Wei JL, Holinger LD. Management of foreign bodies of the airway. In: Shields TW, editor. General thoracic surgery. Volume 1, 6th ed. Philedelphia: Lippincott Williams Wilkins; 2005. p. 995-1005. 